France in Tokyo

\section{Two heads better than one?}

France has had two heads at the economic summit in Tokyo, one of them gung-ho for technological cooperation, and the other apparently lukewarm. The future of French policy in this increasingly important area of politics, which covers matters from the Strategic Defense Initiative (SDI) to joint industrial development and the mobility of scientists, is thus becoming somewhat murky.

At previous summits, President François Mitterrand, head of state and a socialist, has blown the trumpet for technology. His ministers, until the March election which threw them out, energetically pursued at least European cooperation in high technology and research. He launched Eureka, a kind of European civil answer to SDI. From the new Prime Minister, the right-wing Jacques Chirac, who is accompanying Mitterrand in Tokyo, little has been heard on these matters, apart from his proposing a candidate for foreign minister who was highly favourable to French government participation in SDI. Mitterrand vetoed the appointment: he believes out-and-out French participation will lead to a braindrain, and a loss of French control of important new industrial technologies.

If this was a negative step (in the sense of international cooperation in technology), Chirac has also taken negative steps in his major reduction of the French research budget (see Nature 321, 8; 1986) - which will reduce the capacity of French bodies to join international collaborations - and in a sweeping reduction in the powers of the research ministry, which has lost control of technology policy grammes (such as space and energy) to the traditionally inward-looking ministry of industry.

Meanwhile other major divisions seem likely to plague the house of French international cooperation. A highly competent official, Robert Chabbal, ex-director of parties have lost influence. identify. as well as a number of technological pro-

science for the North Atlantic Treaty Organisation (NATO), has been appointed coordinator for international research affairs, but he will reside in the weakened ministry of research. The ministry's links with the Elysée, President Mitterrand's palace and office across the Seine, were originally strong and well-used in the development of Eureka, but they must now seem somewhat redundant as both

The demise of the ministry of research was clear in the new government's attributions of power and budget: the decline of the Elysée is less easy to

When before the election Mitterrand was discussing the possible "cohabitation", as the French like to call it, between himself and a potential rightwing prime minister, he made it clear that he would hold on to one thing: foreign policy. This area of action for the President would of course include his dreams of a "technological Europe", driven by France.

Since the election, however, Chirac, apart from losing his first choice of foreign minister, who might anyway have been a symbolic sacrifice, has made it clear that he, not the President, will determine French foreign policy. Chirac had made four foreign tours before the visit to Tokyo to establish his links with French Africa, and the British, German and Italian Prime Ministers, while President Mitterrand has remained at home. Moreover, Chirac has established a private foreign policy advisory unit in his offices in the Hôtel Matignon, and it seems clear now that French foreign policy is being run by Chirac and the foreign ministry at the Quai d'Orsay. Links between the Elysée, where the Eureka programme originated, and the ministry of research are therefore unlikely to have the importance they once did; in Tokyo, Mitterrand is little more than a constitutional monarch, and his past presidential pro-

\section{ESF joins Ocean Drilling Program \\ Washington

\section{planning and site selection.}

THe European Science Foundation (ESF) has signed on as the seventh member of the Ocean Drilling Program (ODP), an international project for ocean basin exploration. ESF has been interested in joining for some time, but the $\$ 2.5$ million membership price tag was a stumbling block that has only recently been overcome.

As an ODP member, ESF can send two scientific representatives on each ODP cruise, and one co-chief scientist each year. ESF will also participate in mission
Representatives of ESF and the National Science Foundation signed the memorandum of understanding sealing the deal at a meeting in Annapolis, Maryland, last week of the ODP executive committee. ESF joins France, West Germany, the United Kingdom, Japan, Canada and the United States as members of ODP. A representative of the Soviet Union attending the Annapolis meeting indicated that his country is seriously considering rejoining ODP, but has not yet made a decision on that score.

\section{Good week for} Pasteur institute

The Institut Pasteur, the biological and medical research institute in Paris founded by Louis Pasteur in the nineteenth century, has learned from a US court that it may, after all, be granted priority in its patent dispute with the US National Institutes of Health over who first invented blood tests for AIDS (acquired immune deficiency syndrome).

Millions of dollars could be involved in the argument, which dates back to September 1983, when the Pasteur filed a patent based on the discovery by its researcher Luc Montagnier of the virus that causes AIDS ("HIV", according to the recommended new nomenclature). Robert Gallo of NIH filed a similar patent based on his own work many months later, and was awarded his while the French application is still pending.

Now, the US Patents and Trademakers Office has announced "an interference" between the applications, in terms which, according to the Pasteur, mean that the institute will be awarded the patent rights unless Dr Gallo can prove prior discovery of HIV. Here Pasteur scientists feel on firm ground, but recent statements by Gallo (see p. 119) may give cause for doubt.

Moreover, all is not yet jubilation in Paris, as a final judgement in the US courts will take two years, and any redistribution of royalties on tests will take place only from the date of the judgement and will not be retroactive. Meanwhile, attempts to achieve a negotiated end to the dispute continue, and at the Pasteur (already heartened by a bequest from the Duchess of Windsor) they now feel they have a trump card.

Robert Walgate

nouncements on a new world of technology merely echoes.

What everyone is waiting for, however, is to see where the new power, Chirac, moves in this area. His new foreign policy advisers have a strong industrial slant. Their chief is François Bujon de l'Estang (not to be confused with ex-President Giscard d'Estaing), a past international relations director of the French atomic energy agency (CEA), head of the US subsidiary of the nuclear fuel company COGEMA and chief cabinet adviser to Giscard d'Estaing's minister of industry, André Giraud. Moreover, Chirac's ministry of industry is as strong as the ministry of research is now weak. However, with the appointment as his science adviser of Yves Durant, an advocate of the freedom of research from state interference, who will be counselling Chirac to reduce the power of the ministry of research and its organizations still further, the chance of a renewed campaign by France for a research-led, high-technology future seems small.

Robert Walgate 